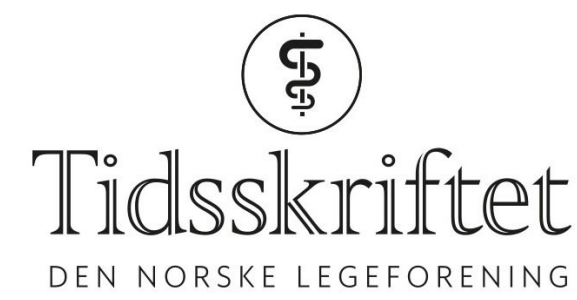

\title{
Unntak fra taushetsplikten?
}

KOMMENTAR

INGER H. BLESKESTAD

E-post: inger.hjordis.bleskestad@sus.no

Inger H. Bleskestad er forskningssjef, overlege og $\mathrm{PhD}$.

Ingen oppgitte interessekonflikter.

\section{GEIR SVERRE BRAUT}

Geir Sverre Braut er seniorrådgiver og professor ved Stavanger universitetssjukehus. Ingen oppgitte interessekonflikter.

I en originalartikkel i Tidsskriftet presenteres en undersøkelse av utviklingen av hysterektomier ved St. Olavs hospital gjennom nærmere zo år (1). Det prisverdig at slike undersøkelser blir gjort med en vitenskapelig tilnærming og at resultatene blir publisert gjennom anerkjente tidsskrifter.

I metodedelen av artikkelen redegjør forfatterne for forhåndsvurderingen av studien. Den ble forelagt Regional komite for medisinsk og helsefaglig forskningsetikk (REK). REK konkluderte med at det var en kvalitetsstudie. Forfatterne trekker da slutningen at det dermed ikke er nødvendig med formell godkjenning. Det mener vi er feil.

Opplysningene som artikkelen er bygget på stammer fra pasientjournalene ved sykehuset, altså taushetsbelagt informasjon. For at det skal kunne gjøres et journaloppslag uten at det innhentes samtykke fra pasientene, må det foreligge et gyldig unntak fra taushetsplikten. REK har uttalt at studien ikke faller inn under helseforskningsloven. Når det gjelder forskningsprosjekter som ikke faller inn under helseforskningsloven, er REK delegert myndigheten til å innvilge unntak med hjemmel i § 29 annet ledd i helsepersonelloven. Det framkommer ikke av artikkelen at det foreligger her. Annet gyldig unntak fra taushetsplikten må derfor framskaffes, før oppslag kan gjøres.

For at unntak fra taushetsplikten med hjemmel i bestemmelsene om kvalitetssikring i § 26 i helsepersonelloven skal kunne komme til anvendelse, må det foreligge et oppdrag fra ledelsen ved sykehuset for å se på kvaliteten av behandlingstilbudet med det formålet å sikre, eventuelt bedre denne. Ved helseforetakene i Norge er det vanlig praksis at personvernombudet (PVO) er gitt tilrådningsmyndighet for slike kvalitetssikringsstudier, i tillegg til det som følger direkte av personopplysningsloven med forskrift. En forhåndsvurdering av personvernombudet innebærer da en vurdering av nødvendighet og relevans av de opplysningene som innhentes opp mot studiens formål.

Videre er det opplyst at studiedatabasen ble oppbevart på minnepenn i låst arkivskap etter godkjenning av Det medisinske fakultet ved NTNU. Det er vanskelig å se hva sags myndighet universitetet har for å godkjenne datalagringen ved en intern kvalitetssikringsstudie med sykehuset som databehandlingsansvarlig. Dette er også noe som personvernombudet etter 
bestemmelsene i personopplysningsloven skal ta stilling til, dersom det for denne studien ikke er innvilget en egen konsesjon fra Datatilsynet.

Vi savner altså en noe mer utfyllende redegjørelse for forhåndsvurderinger som synliggjør hjemmelsgrunnlag for unntak fra taushetsplikten og for etablering og lagring av en database knyttet til studien. Dette opplever vi som stadig tilbakevendende utfordringer ved sykehusene, og nettopp derfor ser vi gjerne at det gis en presis omtale av hvordan lovkravene knyttet til innsyn i og behandling av taushetsbelagte opplysninger er tilfredsstilt ikke bare i ordinære kliniske forskningsstudier, men også i kvalitetssikringsprosjekter.

LITTERATUR:

1. Denstad SE, Aasen S, Østrem AM et al. Hysterektomi ved St. Olavs hospital 1989-2014. Tidsskr Nor Legeforen 2017; 137: 1191 - 6. [PubMed]

Publisert: 28. november 2017. Tidsskr Nor Legeforen. DOI: 10.4045/tidsskr.17.0970

(C) Tidsskrift for Den norske legeforening 2020. Lastet ned fra tidsskriftet.no 